\title{
EFFECTIVE TECHNOLOGIES OF SEVERE PLASTIC DEFORMATION
}

\author{
${ }^{1}$ Abdrakhman NAIZABEKOV, ${ }^{1}$ Sergey LEZHNEV, ${ }^{2}$ Yevgeniy PANIN, ${ }^{3}$ Alexandr ARBUZ, \\ ${ }^{2}$ Irina VOLOKITINA, ${ }^{2}$ Andrey VOLOKITIN \\ ${ }^{1}$ Rudny Industrial institute, Rudny, Kazakhstan; \\ ${ }^{2}$ Karaganda state industrial university, Temirtau, Kazakhstan; \\ ${ }^{3}$ Nazarbayev University, Nur-Sultan, Kazakhstan, sergey legnev@gmail.com
}

https://doi.org/10.37904/metal.2020.3465

\begin{abstract}
Creation of new structural materials with new unique properties of metal remains one of the urgent tasks of modern materials science. In practice, it is possible to improve the properties of existing structural materials by grinding their structure to an ultra-fine-grained state. At the moment, one of the promising ways to obtain an ultra-fine-grained structure is the severe plastic deformation method (SPD). Most of the currently existing methods of implementation of the SPD have not been used in the real industrial sector due to the existing in this method of deformation of the disadvantage, which is the discreteness, i.e. the inability to process products of relatively long length and the need for a large number of processing cycles. And this determines the economic inexpediency of the introduction of this method in production. To solve the problem of introduction of the technology of production of ultra-fine-grained materials by SPD methods, we have developed a number of combined technologies of deformation, allowing to obtain rods of rectangular and circular cross-section of ferrous and non-ferrous metals with ultra-fine-grained structure. These processes include the following combined methods: "rolling-ECAP", "ECAP-drawing" "screw rolling-ECAP". As a result of numerous laboratory studies, to study the effect of the proposed methods of deformation on the microstructure evolution of various structural materials and change their properties, it was proved that the combined processes "rolling-ECAP" and "screw rolling - ECAP" have undeniable advantages over conventional equal-channel angular pressing, both in terms of more intensive grinding of grain and higher mechanical characteristics of the deformable metal in one cycle of deformation, and in terms of the possibility of obtaining long blanks.
\end{abstract}

Keywords: Severe plastic deformation, ultra-fine-grained materials, combined processes, microstructure evolution

\section{INTRODUCTION}

One of the actual problems of modern materials science is still the problem of obtaining new structural materials with new unique properties. At the same time, it is not necessary to obtain completely new structural materials, but it is enough to improve the properties of existing structural materials by grinding their structure to an ultrafine-grained state. One of the most promising ways to obtain ultrafine structure in ferrous and non-ferrous metals and alloys is the method of implementation of severe plastic deformation (SPD) during metal forming.

The most often considered method of SPD realization at metal forming is equal-channel angular pressing (ECAP) [1] which for 6-10 cycles provides grinding of metal microstructure to an ultrafine state. Over the past decade, to reduce the required number of ECAP cycles in the production of metal with a given grain size, a number of matrices of various modifications have been developed to ensure the implementation of this method of deformation [2-13]. But all these proposed matrices for ECAP had not found application in real industrial sector due to the ECAP method flaws:

1) discreteness, i.e. the impossibility of processing a large length billets; 
2) need for a large number of processing cycles.

It is these two main drawbacks that determine the economic inexpediency of introducing the ECAP method into production.

In order to solve the still standing problem of developing an economically feasible technology for the introduction into production of ultrafine materials by methods of severe plastic deformation, we have developed a number of combined deformation processes. These include the following processes: "rolling-ECAP" [14-18]

(Figure 1a), "screw rolling-ECAP" [19] (Figure 1b), "ECAP-drawing" [20] (Figure 1c).

\section{CONCEPT OF COMBINED PROCESSES}

The essence of the proposed combined deformation processes "rolling-ECAP", "screw rolling-ECAP" (Figure 1a, b) is as follows. Pre-heated to the deformation temperature (for some non-ferrous metals it is possible at room temperature), the workpiece is fed to the rolling rolls, which due to contact friction forces captured it in the rolls gap, at the exit from it is pushed through the channels of the ECAP matrix. In this case, the process of pressing blanks in an equal-channel stepped matrix is realized by using the contact friction forces arising on the surface of the metal contact with the rotating rolls.

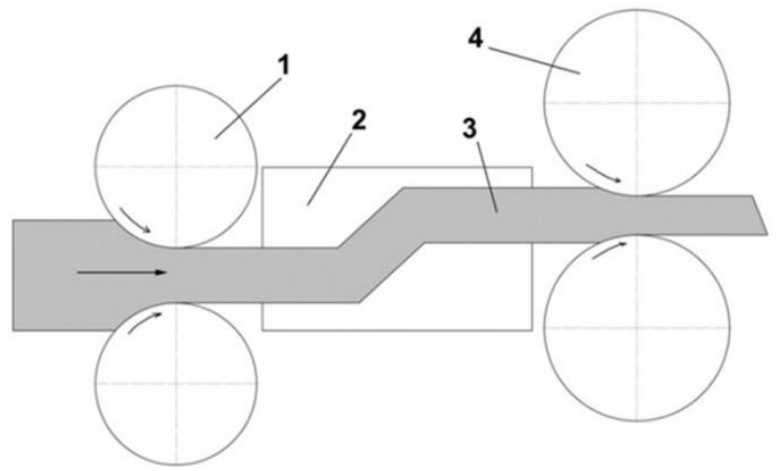

a)

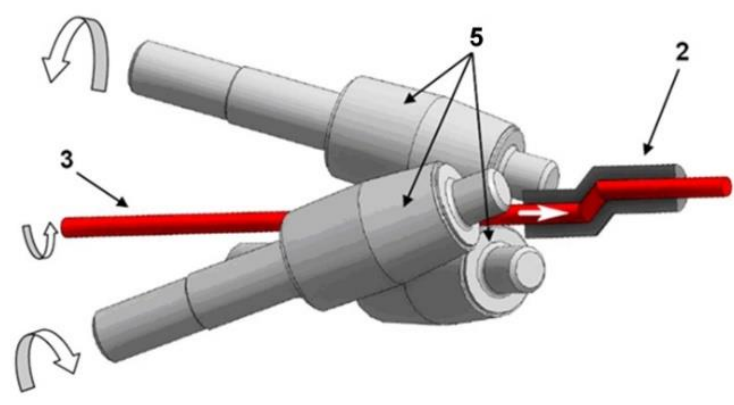

b)

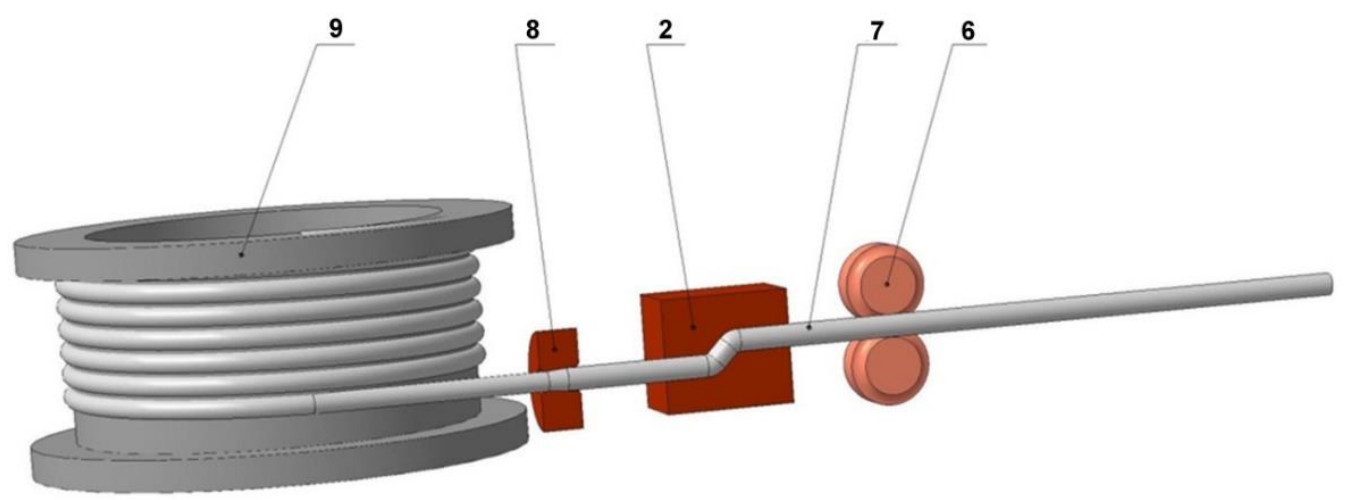

C)

1 - the $1^{\text {st }}$ pair of rolls; 2 - ECAP matrix; 3 - workpiece; 4 - the $2^{\text {nd }}$ pair of rolls; 5 -conical rolls; 6 - pushing device; 7 - wire; 8 - drawing die; 9 - winding drum

Figure 1 Scheme of combined processes

In the implementation of the combined process "rolling-ECAP" when workpiece is completely out of the matrix channels, it is captured by the second pair of rolls, which also due to the contact friction forces capture the workpiece and completely pull it out of the matrix. In the implementation of the combined process "screw 
rolling-ECAP" after the workpiece is completely out of the rolls gap, the next workpiece is fed to them, which, moving through the rolls and matrix, pushes the previously deformed workpiece out of the matrix.

The combination of the rolling process (longitudinal and screw) and subsequent pressing in an ECAP matrix allows to realize a favorable scheme of the stress-strain state with the implementation of severe plastic deformation in the entire volume of the deformed metal, which creates good conditions for the formation of an ultra-fine-grained structure in it.

The essence of the proposed combined deformation process "ECAP-drawing" (Figure 1c) is as follows. The pre-pointed end of the wire is set in an ECAP matrix, and then sequentially in the drawing die (in essence, the process of the metal supply does not differ from the wire supply in the drawing die during the standard drawing process). After the end of the workpiece comes out of the drawing die, it is fixed with gripping tongs and wound on the drawing mill drum. In this case, the process of stretching the workpiece through an ECAP matrix and drawing die is realized by applying a pulling force to the end of the workpiece. An external load is applied to the metal being stretched, and contact stresses occur on the metal-tool contact surface. Unlike other metal forming methods, during this combined process implementation the presence of contact friction forces on the metal-tool section, directed against the movement of the metal, is negative phenomena of the process, which undoubtedly implies the use of technological lubricants that reduce friction.

\section{EXPERIMENTAL DATA}

As a result of numerous laboratory studies on the influence of the proposed deformation methods on the microstructure evolution of various structural materials (ferrous and non-ferrous metals and alloys) and changes in their properties, it was proved that the combined processes "rolling-ECAP", "screw rolling-ECAP" and "ECAP - drawing" have undeniable advantages over conventional ECAP, both in terms of more intensive grain grinding and higher mechanical characteristics of the deformed metal in one deformation cycle, and in terms of the possibility of obtaining long blanks [20-22].

In the course of one of these laboratory studies, an experiment was carried out on the deformation of blanks made of technical pure copper M1 with dimensions of $15 \times 25 \times 450 \mathrm{~mm}$ (the blanks were subjected to annealing before deformation) on the installation implementing the combined process "rolling-ECAP". The aim of the experiment was to study the effect of a new combined process of plastic deformation "rolling-ECAP" on the structure and mechanical properties of copper and to identify the advantages of the proposed technology compared to the current technology of equal-channel angular pressing in a stepped matrix.

It was decided to conduct three cycles of deformation, which was justified by the presence of three sets of equal-channel stepped matrix with the following geometric parameters: the angle of the junction of the channels was 140 degrees, the channel width was equal to $40 \mathrm{~mm}$, and the height of the channels was 13,8 and $6 \mathrm{~mm}$, respectively.

The scheme of deformation according to the proposed technology was as follows:

- $\quad$ 1st pass: the workpiece with height of $15 \mathrm{~mm}$ rolled $3 \mathrm{~mm}$ in the first pair of rolls, passed through the matrix with a channel height of $13 \mathrm{~mm}$ and then rolled $3 \mathrm{~mm}$ in the second pair of rolls;

- 2nd pass: the workpiece with height of $10 \mathrm{~mm}$ rolled $3 \mathrm{~mm}$ in the first pair of rolls, passed through the matrix with a channel height of $8 \mathrm{~mm}$ and then rolled $1 \mathrm{~mm}$ in the second pair of rolls;

- $\quad 3 r d$ pass: the workpiece with height of $7 \mathrm{~mm}$ rolled $2 \mathrm{~mm}$ in the first pair of rolls, passed through the matrix with a channel height of $6 \mathrm{~mm}$ and then rolled $1 \mathrm{~mm}$ in the second pair of rolls.

To identify the advantages of the proposed technology in comparison with the current technology of equalchannel angular pressing in a stepped matrix, three cycles of ECAP deformation of billets with dimensions of $13 \times 25 \times 150 \mathrm{~mm}$ from M1 annealed technical copper were carried out. As a deforming tool, an equal-channel stepped matrix with a channel height of $13 \mathrm{~mm}$ for the first pass was used. 
After each deformation cycle, templates were prepared to study the mechanical properties and microstructure of M1 technical copper. The microstructure of the prepared samples was studied using optical and transmission electron microscopes.

Samples for the mechanical properties study were made as standard tensile samples, according to GOST 11701-84 "Methods of tensile testing of thin sheets and tapes". The study of mechanical characteristics was carried out on the INSTRON torsion-bursting machine.

For the preparation of samples for transmission microscopy the high-precision cutting machine AccuTom-5 was used, which cut off the plate thickness of $0.3 \mathrm{~mm}$. Then, using a special punch the discs with a diameter of $3 \mathrm{~mm}$ were knocked out. Etching of the prepared discs was made in automatic mode on the electro-polishing unit TenuPol in D2 proprietary electrolyte until the hole in the sample, after which the process automatically stopped. The selected samples were studied on a transmission electron microscope Jeol JEM-2100 under an accelerating voltage of $300 \mathrm{kV}$.

\section{RESULS AND DISCUSSION}

The results of the microstructure study of M1 copper alloy before and after deformation by the proposed technologies are presented in Figure 2.

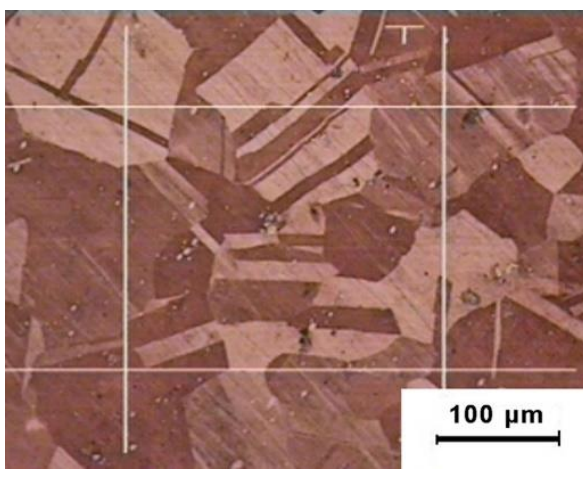

a)

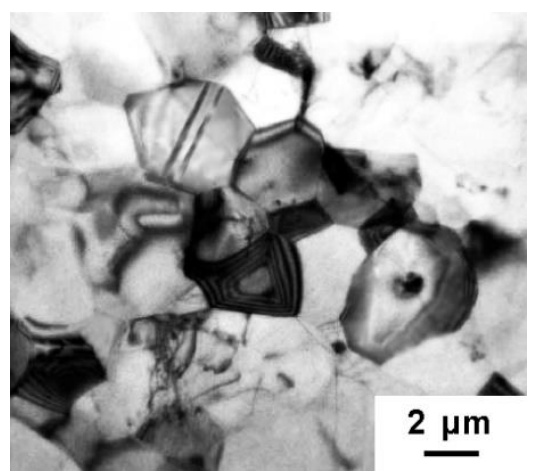

b)

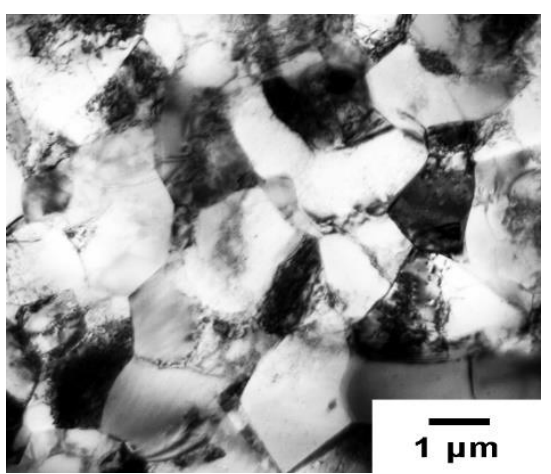

C)

a - initial structure; $b$ - after ECAP; $c$ - after combined process "rolling-ECAP"

Figure 2 Microstructure of M1 alloy after 3 deformation cycles

The results of mechanical studies are presented in Table 1. Strength characteristics of copper are represented by values of yield strength, tensile strength and microhardness; plastic characteristics are represented by values of relative contraction and elongation of samples before fracture.

Table 1 Results of mechanical tests of samples

\begin{tabular}{|l|c|c|c|c|c|}
\hline Technology & Tensile strength, MPa & Yield strength, MPa & Elongation, \% & Contraction, \% & HV \\
\hline Annealed state & 235 & 198 & 25.0 & 57.0 & 104 \\
\hline ECAP & 465 & 386 & 14.0 & 37.0 & 229 \\
\hline Rolling-ECAP & 482 & 405 & 17.0 & 50.0 & 236 \\
\hline
\end{tabular}

Metallographic analysis of copper billets revealed that in the initial annealed state copper has a fairly coarsegrained structure with a large presence of twins and an average grain size of 90 microns (Figure 2a). Also, the analysis showed that after the first cycle of deformation, the structure of copper is strongly crushed to 40 $\mu \mathrm{m}$ after ECAP and up to $35 \mu \mathrm{m}$ after the combined process "rolling-ECAP". In cross-section, the microstructure is quite uniform, it is dominated by approximately equiaxial grains. In the longitudinal section of 
the workpiece there is a small elongation of the grains. This distinct difference in grain shapes in the longitudinal and transverse directions is explained by the action of two types of deformation (ECAP and rolling), which have different schemes of stress-strain state. There is a decrease in the boundary distances in the longitudinal and cross sections at the rolling stage. This decrease is due to the geometric effect of deformation - the compression of the initial grains. The formation of new boundaries during rolling practically does not occur, all fragmentation of the structure occurs in an equal-channel step matrix under shear deformations due to twinning.

After the second deformation cycle, the copper structure is reduced to $20 \mu \mathrm{m}$ after ECAP and $14 \mu \mathrm{m}$ after the combined process. Two types of grains were found in the structure of copper: small recrystallized and deformed. This structure is caused by two processes: recrystallization during rolling and fragmentation in an equal-channel step matrix.

After the third cycle, the structure of copper is reduced to 5 microns after ECAP (Figure $\mathbf{2 b}$ ) and $2 \mu \mathrm{m}$ after the combined process (Figure 2c). The structure shows a significant increase in the proportion of large-angle boundaries due to more active processes of dynamic return and recrystallization. This is due to the fact that as the grain decreases, the temperature of the beginning of recrystallization decreases. The grain boundaries become more clear. In cross-section, the microstructure is uniform, with equiaxed grains. In the longitudinal section of the workpiece grain have an elongated shape, which is a consequence of the two stages of rolling in each pass.

After analyzing Table 1, it can be concluded that the strength properties of copper in both deformation processes were increased, which corresponds to the Hall-Petch equation, and the plastic properties were reduced. Thus, the yield strength for three cycles of deformation increased by 2.04 times, which is $10 \%$ more than at ECAP; tensile strength increased by 2.05 times, which is $7 \%$ more than at ECAP, and elongation decreased by $44 \%$, which is $12 \%$ less than at ECAP.

\section{CONCLUSION}

The implementation and bringing to industrial use of the proposed combined processes "rolling-ECAP", "screw rolling - ECAP" will allow to obtain high-quality rod of rectangular and round cross-section, or high-quality wire, in the case of implementing the combined process "ECAP-drawing". The economic and energy efficiency of the proposed deformation technologies in comparison with the traditional ECAP technology is to reduce the number of deformation cycles necessary to obtain a uniform ultra-fine grained structure and a larger specific volume of material produced in one processing cycle by ensuring the continuity of the process, which is subjected to numerous studies, given in the works [18-20]. This allows to talk about the advantages of the proposed combined deformation processes and prospects for their commercial application.

\section{REFERENCES}

[1] VALIEV R.Z., ALEKSANDROV I.V. Nanostrukturnye materialy, poluchennye intensivnoj plasticheskoj deformaciej. M.: LOGOS, 2000.

[2] VALIEV R.Z., LANGDON T.G. Principles of equal-channel angular pressing as a processing tool for grain refinement. Progress in Materials Science. 2006, vol. 51, pp. 881-981.

[3] NAIZABEKOV A.B., LEZHNEV S.N., ARBUZ A.S. Konechno-elementnoe modelirovanie RKU pressovaniya s kvazisverhmalymi uglami styka kanalov. In: Mezhdunarodnyj nauchno-tekhnicheskij progress OMD-2014 «Fundamental'nye problemy. Innovacionnye materialy i tekhnologii». Moskva, 2014, pp. 206-210.

[4] UTYASHEV F.Z., RAAB G.I. Vliyanie ochaga deformacii na izmel'chenie struktury v metallah. Fizika metallov $i$ metallovedenie. 2007, vol. 6, pp. 104-109.

[5] RAAB G.I., KULYASOV G.V., POLOZOVSKIJ V.A., VALIEV R.Z. Ustrojstvo dlya obrabotki metallov davleniem. RUS. IPC B21D 25/02, B21C 25/00. Patent RF № 2181314. 2002. 
[6] ROSOCHOWSKI A. Severe plastic deformation of metals. UK. Patent №1861211. 2007

[7] OLEJNIK L., ROSOCHOWSKI A. Methods of fabricating metals for nano-technology. Bulletin of the Polish Academy of Sciences - Technical sciences. 2005, vol. 53, no. 4, pp. 413-423.

[8] VALIEV R.Z., SALIMGAREEV H.Sh., RAAB G.I., KRASIL'NIKOV N.A., AMIRHANOV N.M. Sposob kombinirovannoj intensivnoj plasticheskoj deformacii zagotovok. Patent RF №2240197. 2004.

[9] IVANOV A.M., ALEKSANDROVA E.S. Ustrojstvo dlya mnogo-ravnokanal'nogo uglovogo pressovaniya zagotovki. Patent RF №2492950. 2013.

[10] OVECHKIN L.M., SOSENUSHKIN A.E., SOSENUSHKIN E.N. Shtamp dlya ravnokanal'nogo uglovogo pressovaniya. Patent RF №2440210. 2012.

[11] BELOKOPYTOV V.V., SOSENUSHKIN A.E., SOSENUSHKIN E.N., CFAS G.M., YANOVSKAYA E.A. Shtamp dlya uglovogo pressovaniya. Patent RF №250962. 2014.

[12] SHERKUNOV V.G., SEMASHKO M.Yu., CHIGINCEV P.A., PROHOROV Yu.F. Ustrojstvo dlya mnogociklovogo ravnokanal'nogo uglovogo pressovaniya zagotovok. Patent na poleznuyu model' RF №154583. 2015.

[13] GRESHNOV V.M., DMITRIEV A.M. Sposob pressovaniya metallov i ustrojstvo dlya ego osushchestvleniya. Patent RF № 2329108. 2008.

[14] NAIZABEKOV A.B., LEZHNEV S.N., PANIN E.A. Ustrojstvo dlya nepreryvnogo pressovaniya metalla. Patent RK № 23802. 2012.

[15] NAIZABEKOV A.B., LEZHNEV S.N., PANIN E.A. Ustrojstvo dlya nepreryvnogo pressovaniya metallov i splavov. Patent RK №25862. 2013.

[16] NAIZABEKOV A.B., LEZHNEV S.N., PANIN E.A. Ustrojstvo dlya nepreryvnogo pressovaniya metalla. Patent RK №25863. 2013.

[17] NAIZABEKOV A.B., LEZHNEV S.N., PANIN E.A. Ustrojstvo dlya nepreryvnogo pressovaniya metallov i splavov. Patent RK №27262. 2016.

[18] MAZUR I.P., LEZHNEV S.N., NAIZABEKOV A.B., PANIN E.A., VEDISHCHEV R.O, Ustrojstvo dlya nepreryvnogo pressovaniya metallov i splavov, Patent RF № 2629134. 2017.

[19] NAIZABEKOV A.B., LEZHNEV S.N., ARBUZ A.S. Ustrojstvo dlya nepreryvnogo pressovaniya metalla. Patent RK №27445. 2016.

[20] VOLOKITIN A.V., NAIZABEKOV A.B., LEZHNEV S.N. et al. Issledovanie formirovaniya ul'tramelkozernistoj struktury i svojstv metallicheskih materialov, podvergnutyh pressovaniyu $v$ ravnokanal'noj stupenchatoj matrice $s$ posleduyushchim volocheniem: Monografiya. Rudnyj: RIl, 2019.

[21] PANIN E.A., NAIZABEKOV A.B., LEZHNEV S.N. et al. Theoretical and technological bases of obtaining sub ultrafine-grained structural metals and alloys by new combined process "rolling - ECA-pressing»: Monograph. Rudny: RII, 2018.

[22] NAIZABEKOV A.B., LEZHNEV S.N., ARBUZ A.S. et al. Teoreticheskie i tekhnologicheskie osnovy polucheniya subul'tramelkozernistyh konstrukcionnyh metallov $i$ splavov novym sovmeshchennym processom «vintovaya prokatka - RKU-pressovanie»: Monografiya. Rudny: RII, 2017. 